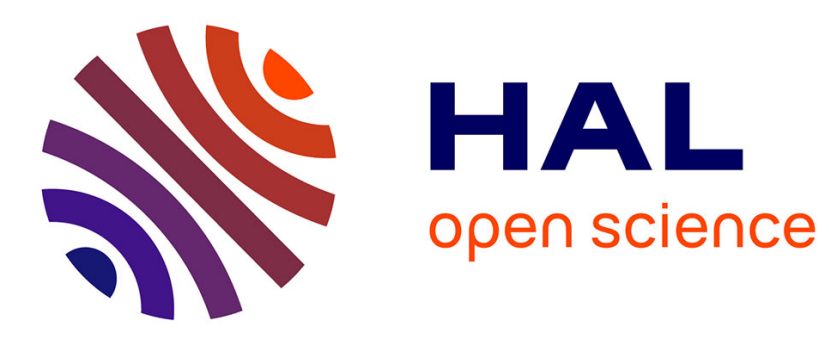

\title{
Plastic behaviours of polycrystalline metals under multi-axial cyclic loading conditions and constitutve equations
}

\author{
Masataka Tokuda, Masashi Kuroyanagi
}

\section{- To cite this version:}

Masataka Tokuda, Masashi Kuroyanagi. Plastic behaviours of polycrystalline metals under multiaxial cyclic loading conditions and constitutve equations. Revue de Physique Appliquée, 1988, 23 (4), pp.700-700. 10.1051/rphysap:01988002304070000 . jpa-00245856

\section{HAL Id: jpa-00245856 https://hal.science/jpa-00245856}

Submitted on 1 Jan 1988

HAL is a multi-disciplinary open access archive for the deposit and dissemination of scientific research documents, whether they are published or not. The documents may come from teaching and research institutions in France or abroad, or from public or private research centers.
L'archive ouverte pluridisciplinaire HAL, est destinée au dépôt et à la diffusion de documents scientifiques de niveau recherche, publiés ou non, émanant des établissements d'enseignement et de recherche français ou étrangers, des laboratoires publics ou privés. 


\title{
PLASTIC BEHAVIOURS OF POLYCRYSTALLINE METALS UNDER MULTI-AXIAL CYCLIC LOADING CONDITIONS AND CONSTITUTVE EQUATIONS
}

\author{
Masataka TOKUDA and Masashi KUROYANAGI
}

Dept. of Mech. Eng., Mie Univ., Kamihama, Tsu 514, JAPAN

The authors have been investigating plastic behaviours of polycrystalline metals experimentally by applying combined loads of a cyclic axial force with constant strain amplitude and a stationary internal pressure to thin-walled tubular specimens made of brass. Increases of circumferential strain $\varepsilon_{\vartheta}$ observed in such systematic and precise experiments are very much suggestive for a study on mechanisms of plastic behaviours of polycrystalline metals. When a circumferential stress due to the internal pressure is small comparatively to an amplitude of axial stress, the circumferential strain called a mechanical ratcheting strain increases gradually with the number of cycles $\mathrm{N}$ of axial strain, and a shape of $\varepsilon_{g}-\mathrm{N}$ curve is similar to that of a typical axial strain-time curve obtained by (constant axial stress) creep test, which has so called the first (transient) stage and the second (stationary) stage. When we consider a slip mechanism to be only one mechanism producing the plastic deformation, such an experimental observation can be explained by a change of the number of active slip systems in each single crystal component during the cyclic deformation process(1). Moreover, an amount of mechanical ratcheting strain is very sensitive to the number of active slip systems. That is, in order to formulate plastic constitutitve equations which can predict such the increase of ratcheting strain in a reasonable accuracy, the number of active slip systems during cyclic deformation have to be incorprated in a very careful way.

As diccussed recently by Mughrabi (2) Mecking(3), Leffers (4), the number of active slip systems of crystal component in polycrystal under cyclic deformation process may be kept one by an occur of persistent slip band when the amplitude is small, and in this case, sacks type model (stress constant model) may be rather applicable. On ther other hand, when the amplitude is large, the compatibility can not be satisfied by small number of slip sytems, and in this case, Taylor model (five slip systems are active; plastic strain constant idea) or Lin's model (the number of active slip systems changes from one to five rather quicky in an earlier stage of deformation; strain constant ideal may be rather suitable much more than the Sacks model. As discussed by Ashby (5), inhomogeneous distributions of dislocations, e.g., arrays of dislocations along grain boundaries, keep the number of active slip systems smaller than that predicted by assuming that each single crystal grain deforms uniformly in the polycrystal. Canova et al $(6)$ suggested so called relaxed constrained model whcih is one way to overcome such a problem in a large deformation range. This method can not be used for our case. It may be possible to modify the self-consistent model to incorporate such effects while the uniform distributionsof stress and strain in each single crystal components are assumed to be kept practically. This idea comes directly from a suggestion of Zaoui-Berveiller(7). The original self-consistent model proposed Kroner and Budiansky-Wu gives the following relation between micro- and macrovariables.

$$
(1-\lambda / 2)\left(s_{i j}-s_{i j}^{*}\right)-\lambda G\left(e_{i j}-e_{i j}^{*}\right)=0 . .
$$

where $\lambda=2(7-5 v) /[15(1-v)], s_{i j}^{*}, e_{i j}^{*}$ are stress deviator and strain deviator of single crystal components and $s_{i j}$ and $e_{i j}$ are averaged stress deviator and strain deviator of polycrystal. That is, the original self-consistent model can be changed to Sacks modle if we select $\lambda=0$ and to Lin's model if we select $\lambda=2$. Therefore if the non-uniform distributions of stress and strain are assumed to affect plastic behaviours of polycrystalline materials through the number of active slip systems, a modification of the self consistent model by assuming that the accomodation parameter $\lambda$ depends on deformation paths is a significant way to get a more realistic and practical model for reproducing plastic behaviours of polycrystals. The prediction of ratcheting strain produced in multi-axial cyclic deformations may correspond to this case. The parameter $\lambda$ should be estimated to be rather small when the strain amplitude is small, and to be large when the amplitude is large. Based on such an idea, the change of paramter $\lambda$ is incorporated in constitutive equations proposed in the previous paper $(8)$, and the ratcheting strian reproduced by using these equations is confirmed to have a good agreemnt with the experimental observations.

\section{References}

(1) Tokuda, M., Katoh, H., Bulletin of JSME, 29-249(1986), 708

(2) Mughrabi, M., Wang, R., Proc. of 2 nd Riso Int. Conf. on Metall.and Mate.s Sci.leds., Hansen, N., Horsewell, A., Leffers, T., Lilholt, H.(1981), p.87, Riso National Lab., Rosklide, Denmark

(3) Mecking, H., ibide., p.73

(4) Leffers, T., ibide., p.55

(5) Ashby, M.F., Brown, A.M., ibide.,p.1

(6) Berveiller, M., Zaoui, A., J.Mech. Phys.Solids, 26(1979), 325

(7) Canova, G.R.,Kocks, U.F., Tome, C.N., Jonas, J.J., J.Mech.Phys.Solids 33-4(1985), p. 371

(8) Tokuda, M., Ohno, N., Kratochvil, J., Proc. of Int.Conf. on Creep, p.411, JSME, IMechE, ASME, ASTM 